\title{
Preliminary Note on a Stratiform Arsenopyrite Mineralization in Quartzphyllites, Pretul-Alpe, Styria, Austria
}

\author{
Von

\section{Richard Göd}

(Vorgelegt in der Sitzung der math.-nat. Klasse am 13. Oktober 2005 durch das w. M. Josef Zemann)

The "Geochemical Atlas of Austria" (Thalmann et al. [8]) shows a notable positive geochemical arsenic anomaly in stream sediments (max.: $400 \mathrm{ppm}$ As) in the Wechsel-Semmering area, locally corresponding to arsenic contents up to $1600 \mathrm{ppm}$ As (current investigation) in soils. Comparable arsenic contents in soils from the Eastern Alps have been discussed by GöD and ZEMANN [2] and GöD and HEISS [1].

The relevant drainage system is composed of monotonous phyllites s.l. belonging to a tectonic unit called "Grobgneisserie" (for the geology see sheet 104 Mürzzuschlag, MANDL [3]). The geology and petrography of these diaphthoritic, most likely prevariscan, phyllites have been summarized by NEUBAUER and SASSI [5] and more recently by SCHUSTER et al. [7].

Based on the geochemical anomalies an As-mineralization was found some $2.5 \mathrm{~km} \mathrm{SW}$ of the summit of the Pretul-Alpe, at an altitude between 1480 and $1570 \mathrm{~m}$ asl and could be traced for more than $600 \mathrm{~m}$ along strike (extensive trenching because of the erection of wind-wheels provided the opportunity to make all these observations). 
The relevant rocks strike NW-SE and dip gently SW $\left(240^{\circ} / 15^{\circ}\right)$. Owing to the overall monotonous character of the rocks delt with, it was not possible to establish a local stratigraphy.

The mineralization is bound to finely laminated quartzitic phyllites composed of quartz-muscovite-chlorite the amounts of which vary in the $\mathrm{mm}$ - to $\mathrm{cm}$-scale. Ilmenite is a continuous component of all the phyllites investigated.

No accurate statement about the mineralization's homogeneity or average thickness can be made at present, however, the maximum thickness observed was approximately $1 \mathrm{~m}$.

Arsenopyrite is by far the dominant ore mineral and is accompanied by subordinate pyrite ( $\ll 5 \%$ of the sulphide content) with local pyrrhotite. Traces of chalcopyrite and covellin were also observed. The sulphides are perfectly arranged to the schistosity and are intimately associated with the mica/chlorite layers, leaving the quartz laminae barren.

Arsenopyrite grains are hypidiomorphic to idiomorphic and may reach a grain size of $1 \mathrm{~mm}$. Pyrite occurs as inclusion in the latter as well as in the matrix. Arsenopyrite may surround chalcopyrite which itself is frequently coated by covellin. No mobilization of the sulphides was observed.

Disregarding traces of copper, the arsenic is not associated with any other element like e.g. Au, Ag, base metals, $\mathrm{Mo}, \mathrm{Sb}, \mathrm{Se}, \mathrm{Tl}$ or $\mathrm{Hg}$. Results of the soil survey outline an As-anomaly, no other element shows anomalous concentrations.

Intercalated layers of tourmaline and quartz (cm-scale) and a single tourmalinite horizon of some $20 \mathrm{~cm}$ thickness have been found in the footwall of the mineralization (phyllites in that area generally enriched in tourmaline have been mentioned already by ROCKENSCHAUB [6]). The tourmalinite, not mineralized itself, is composed of approximately $90 \%$ tourmaline and $10 \%$ quartz. At present, a genetic relation between mineralization and tourmaline (-content) seems to be unlikely.

Stream sediment analyses as well as results of soil geochemistry suggest that these mineralizations are potentially spread over another $10 \mathrm{~km}^{2} \mathrm{~N}$ and $\mathrm{E}$ of the area presently investigated. Equivalent phyllites of the same tectonic unit occur as geologic window some $70 \mathrm{~km}$ to the $\mathrm{E}$ (for the geology see sheet 78 Rust, MATURA and PASCHER [4]). Based on soil geochemistry this area is also arseniferous.

The strictly stratiform nature of the arsenopyrite mineralization, its regional extension and its geochemical uniformity might best be 
explained by a primary, synsedimentary enrichment of arsenic in a pelitic environment.

\section{Acknowledgements}

I would like to thank Prof. Dr. A. BERAN, Institut für Mineralogie und Kristallographie, Universität Wien, and Dr. F. BRANDSTÄTTER, Naturhistorisches Museum, Wien, for their support in determining the ore minerals.

\section{References}

[1] GöD, R., HeISs, G. (1999) Die Arsenanomalie Feistritz am Wechsel, Niederösterreich. Jb. Geol. B.-A. 139: 437-444

[2] GöD, R., ZEMANN, J. (2000) Native arsenic-realgar mineralization in marbles from Saualpe, Carinthia, Austria. Miner. Petrol. 70: 37-53

[3] MANDL, G. W. (2001) Geologische Karte der Republik Österreich, 1:50 000, Blatt 104 Mürzzuschlag. Geol. B.-A., Wien

[4] Matura, A., Pascher, G. (1993) Geologische Karte der Republik Österreich, $1: 50$ 000, Blatt 78 Rust. Geol. B.-A., Wien

[5] Neubauer, F., SASsi, F. P. (1993) The Austro-Alpine Quartzphyllites and Related Palaeozoic Formations. In: von Raumer, J. F., Neubauer, F. (eds.) Pre-Mesozoic Geology in the Alps, pp. 423-439. Springer, Berlin Heidelberg New York

[6] Rockenschaub, M. (1989) Bericht 1990 über geologische Aufnahmen im Kristallin südlich von Mürzzuschlag auf Blatt 104 Mürzzuschlag. Jb. Geol. B.-A. 134/3: 492-493

[7] Schuster, K., Berka, R., Draganits, E., Frank, W., Schuster, R. (2001) Lithologien, Metamorphosegeschichte und tektonischer Bau der kristallinen Einheiten am Alpenostrand. Geol. B.-A., Arbeitstagung Neuberg a. d. Mürz

[8] Thalmann, F., Schermann, O., Schroll, E., Hausberger, E. (1989) Geochemischer Atlas der Republik Österreich 1:1 000 000. Geol. B.-A., Wien

Author's address: Prof. Richard Göd, Institut für Geologische Wissenschaften, Universität Wien, Althanstraße 14, 1090 Wien, Austria. E-Mail: richard.goed@ univie.ac.at. 